\title{
Lost Villages in Masuria: A Polish-German Project to Preserve Cemeteries
}

Carried out by "Sadyba" (the Association for the Protection of Masuria's Cultural Landscape), the Borussia Olsztyn Foundation, the University of Warmia and Masuria in Olsztyn, the Heinrich Heine University Düsseldorf, and the Gerhart-Hauptmann-Haus Foundation. Co-financed by the German-Polish Youth Office.

Cemeteries are often all that remains of Masurian villages destroyed at the end of the Second World War. Hidden in the deep forests of the Puszcza Piska in northeast Poland, they are often hardly distinguishable from other elevated patches of ground. In the course of the past 70 years, moss, bushes and trees have overgrown these old resting places. They cover up the last traces of the Masurian people, who lived in the former East Prussian, now Polish region for centuries, in the borderland between Germany and Poland.

Local initiatives are trying to save what still remains of the cemeteries there. By documenting, cleaning up and signposting the cemeteries, they are making the region's cultural heritage visible again. For two years now, a Polish-German cooperative effort of the Gerhart-Hauptmann-Haus Foundation and students of history and landscape architecture at universities in Düsseldorf and Olsztyn has been doing research on the region. Participating in several work camps, each two weeks long, the students have uncovered the old burial places, documented the layout of the graveyards and researched the history of lost villages in both German and Polish archives. Among other goals, this cooperation is meant to support economic development and tourism in present-day Masuria.

Cemeteries are a common expression of the cultural heritage of a border region and are the focus of the student exchange program carried out in cooperation with several associations, foundations and universities in Germany and Poland. Through the program, young people are dealing with relics of the more than 500-year history of the villages in this multi-ethnic cultural space. They research and document the last traces of those villages and make them visible to the region's current generations.

In the northeast of Poland, the region of Warmia i Mazury (in German Ermland und Masuren and in English Warmia and Masuria) is today a voivodeship of the Republic of Poland. Until 1945 the region was the southern part of the Prussian province of East Prussia and part of the German Reich. Masuria has always been a wooded region, characterized by many lakes, for which it is rightly called the "Land of a Thousand Lakes." Despite its charming landscape and its attractiveness to tourists, Masuria has always been on the periphery, far from economic and political centers. ${ }^{1}$ Nevertheless, Masuria is a European region that, despite being peripheral, has witnessed the crucial conflicts of the twentieth

The report is an extended version of a presentation given at the workshop "Grenze, Gedächtnis, Friedhöfe" held in Prague on September 26 and 27, 2018 and organized by the research consortium Grenze/ $\mathrm{n}$ in Erinnerungskulturen.

1 Andreas Kossert, Masuren. Ostpreußens vergessener Süden (Berlin: Siedler, 2002). 
century and their consequences. In Masuria, the effects of nationalism, conflicts over borders, and the devastation of war can be viewed as sharply as if seen through a magnifying glass.

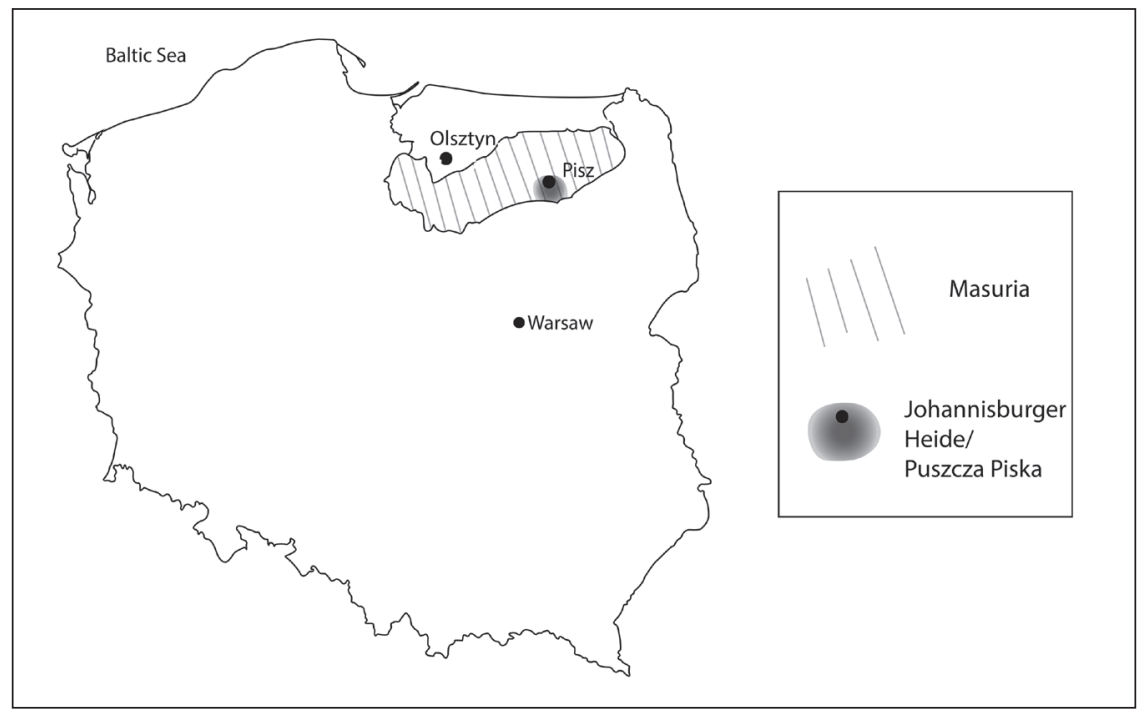

Figure 1: Masuria, Poland

Design: Leo Grabowski

\section{Masuria Through the Centuries}

In the nineteenth and twentieth centuries, both Germans and Poles claimed the region of Masuria as their national territory. In the Middle Ages Masuria was ruled by the Teutonic Order, which supported its development for agriculture. After many battles with their initially pagan Lithuanian neighbors and later with the Polish-Lithuanian Commonwealth, the Teutons agreed to the Treaty of Melno in 1422, which established a border that remained unchanged over the centuries. North of this border, the Order colonized the region and supported its settlement by granting land titles and different kinds of privileges. ${ }^{2}$ The region, which is sometimes called the "Great Wilderness," became the home

2 Grzegorz Białuński, Bevölkerung und Siedlung im ordensstaatlichen und herzoglichen Preußen im Gebiet der "Großen Wildnis" bis 1568 (Hamburg: Verein für Familienforschung in Ost- und Westpreußen, 2009). 
of a vast number of different ethnicities. The remnants of the Prussian tribes destroyed by the Order were joined by Germans, Lithuanians, and above all, Polish migrants from the neighboring region of Mazovia. The latter settlers brought the Polish language with them to the "Great Wilderness" and gave it its name, which is derived from "Mazovia" and later developed into "Masuria." The Masurians spoke a Polish dialect, which was influenced by a number of other languages and peoples. The Masurians were different from their Polish neighbors in the Kurpie and Mazovia regions of Poland, mainly because of their religion: they were Protestants and subjects of the Teutonic Order. As early as 1525, the Order's last Grand Master had founded a temporal duchy with a Protestant orientation, which became the basis for the later Kingdom of Prussia. At the same time, however, they also respected some Catholic rituals, such as pilgrimages to the sanctuaries of Heiligenlinde/ Święta Lipka and Dietrichswalde/Gietrzwałd. ${ }^{3}$

Under the rule of the Teutonic Order, bigger and smaller villages developed along the border with the Polish-Lithuanian Kingdom, which were meant to colonize the hinterland and enhance the military security of the region. In the course of the Order's many conflicts with its eastern neighbors, villagers were time and again conscripted into military service. They suffered violence and destruction in the wars, which did not spare even villages deep in the forest. For that reason, the number of inhabitants scarcely grew for a long period of time. ${ }^{4}$

The region experienced an upswing when the Duchy of Prussia, which had been part of the Electorate of Brandenburg since 1618, became the Kingdom of Prussia in 1701. Since the end of the seventeenth century, the Electors of Brandenburg had founded new villages in the wooded region of Johannisburger Heide, west of the river Pissek. The first inhabitants were woodcutters, charcoal makers and ash burners who were lured to clear and settle in the area by a grant of particularly favorable conditions from Brandenburg. ${ }^{5}$ The Prussian government invested in the region and promoted the timber trade. After the destruction caused by wars against Russia at the end of the eighteenth century, timber from Johannisburger Heide served in the reconstruction of the northern parts of East Prussia. After the Third Partition of Poland in 1795 and the incorporation of parts of Kurpie and Mazovia into Prussia under the name "New East Prussia," Masuria was no longer a true border region, at least temporarily. This state of affairs would only last until the renewed partition of Poland in 1815. That shift of borders resulted in new possibilities for establishing waterways. Accordingly, from 1797 on, the Pissek River was made navigable. Among other things, the goal was to ship timber and possible surpluses of grain to

3 Richard Blanke, Polish-speaking Germans? Language and National Identity among the Masurians since 1871, Ostmitteleuropa in Vergangenheit und Gegenwart, Vol. 24 (Köln: Böhlau, 2001), 42, 222.

4 Wilhelm Sahm, Geschichte der Pest in Ostpreussen (Leipzig: Duncker \& Humblot, 1905), 99, 105; Kossert, Masuren, 73-77.

5 See Emil Johannes Guttzeit, ed., Der Kreis Johannisburg (Würzburg: Holzner Verlag, 1964), 66-71. 
market. ${ }^{6}$ However, even by the time of World War I, no agricultural surpluses were being produced. The inhabitants were hardly able to grow enough food for themselves, as the sandy soil of Johannisburger Heide did not allow for more production. ${ }^{7}$

The region experienced a modest economic boom at the end of the eighteenth century. Iron mills were established at Jaschkowen and, in 1797, at Wondollek, which made commodities such as cast-iron pots, plates, stoves and weights from the locally produced bog iron ore. The iron industry, which was able to sell its products all over East Prussia and as far away as Mazovia until the late nineteenth century, provided the bulk of jobs in the Johannisburger Heide. ${ }^{8}$ A connection to the rail line between Allenstein and Lyck was constructed at the end of the nineteenth century. Another track was built through the Johannisburger Heide to the border settlements of Dlottowen/Fischborn/Dlutowo, ${ }^{9}$ and was extended to Kolno during World War I. Nevertheless, the region remained poor and weak in infrastructure. The mortality rate, particularly among children, was high and began to fall only at the beginning of the twentieth century. ${ }^{10}$ The population of the villages hardly grew, which was mostly due to the emigration of many Masurians to the German Ruhrgebiet, where many from the region tried to build new lives by working in the mining industry. ${ }^{11}$

The Prussian state placed great value on the education of its subjects. Even in the remote region of Masuria, public schools operated from the mid-eighteenth century. ${ }^{12}$ However, education came only slowly to the forest regions. When in the 1830 s the languages used by the inhabitants of the District of Johannisburg were recorded, only a fraction spoke German, and only in the towns. The only language spoken in the villages was "Polish," i.e., Masurian. ${ }^{13}$ An 1834 decree by the Prussian king, who wanted German to

6 Max Töppen, Geschichte Masurens. Ein Beitrag zur preussischen Landes- und Kulturgeschichte, nach gedruckten und ungedruckten Quellen dargestellt (Danzig: Theodor Bertling, 1870; reprint: Aalen: Scientia-Verlag 1969), 391. Citations refer to the reprinted edition.

7 Guttzeit, ed., Der Kreis Johannisburg, 113.

8 Einrichtung Wondollek, Geheimes Staatsarchiv Preußischer Kulturbesitz (hereafter GStAPK), I. HA, Etatsministerium 57 D, Hauptamt Johannisburg, Nr. 446; Ausbau 1809, GStAPK, I., HA, Rep. 87 D, Nr. 2807, Bd. 1.; Töppen, Geschichte Masurens, 392-395; Guttzeit, ed., Der Kreis Johannisburg, 198-199.

9 “Linia Pisz - Kolno," Ogólnopolska Baza Kolejowa, https://www.bazakolejowa.pl/index.php ?dzial=linie\&id=152\&pkno=przebieg.

${ }^{10}$ According to the Church registers of Gehsen, 1846-1876, Evangelisches Zentralarchiv Berlin (hereafter EZA); Sterberegister Gehsen 1877-1944, Archiwum Państwowe w Olsztynie (hereafter APO), 42/1745/1 (those filed under APO after 1877 also under Olsztyn.ap.gov.pl/baza/shany /php?).

${ }^{11}$ Gerhard Wydra, ed., Der Kreis Johannisburg im Wandel der Zeiten (Hamm an der Sieg: Selbstverlag, 1998/99), 197; Kossert, Masuren, 214-220.

12 Guttzeit, ed., Der Kreis Johannisburg, 256.

${ }^{13}$ Einwohnerzahl nach den vorhandenen Sprachen 1832-1841, GStAPK, XX. HA, Rep. 12, Abt. I, Tit. 3, Nr. 1, Bd. 1, Bl. 64-65 and 203. 
be the only language spoken in the schools, provoked fierce protests. Not until 1837 was German the predominant language of instruction in the schools. ${ }^{14}$

In any event, until the founding of the German Reich, children attended school only occasionally in the Johannisburger Heide, although by the 1860 s the state and the Church had firmly urged the population that they should be "attending school until the completion of the fourteenth year of life." 15 In 1871, on the occasion of a census, more than a quarter of the population openly admitted to being illiterate. ${ }^{16}$ We may suppose that there were many more in reality: at the notaries and in the courts it appears that only a few Masurians even knew how to write their own names. ${ }^{17}$

With the rise of nationalism in the nineteenth century, the Masurians became a focus of the national ambitions both of the German and the Polish sides. To safeguard its territory, the Prussian-German state wanted to be sure the Masurians remained loyal subjects. Thus, their customs, including their language, were respected. Indeed, the Masurians proved to be loyal. Their most common first names alone demonstrated their loyalty to the Prussian-German state: typical Masurian names were Wilhelm Podleśny, Amalie Walendziak and Friedrich Podworny. Their first names were German, in most cases referring to the Imperial House, while their surnames were Polish. State subsidies "for the support of Germanness," such as subsidies for the building of community halls, dairies and school choirs, were gratefully accepted. ${ }^{18}$ The subsidies were connected, however, to a clear Germanization policy, which was meant to increasingly enforce the use of the German language among the Masurians. At the same time, the Polish national movement implored the Masurians to admit to their Polishness and shake off centuries-old oppression by Crusaders and the German state. German propaganda - under a different flag - was hardly less explicit. ${ }^{19}$

The Masurians were the first to be hit by World War I in the East, and particularly fiercely. The Johannisburger Heide was occupied twice by Russian troops. There was rape and looting, and males were deported to Russia. ${ }^{20}$ Accounts of destruction at the end of the war showed that 2,800 houses in the District were uninhabitable. ${ }^{21}$

14 Kossert, Masuren, 149-151, 197.

15 Bericht Konsistorialrat Weiß an den Oberkirchenrat, 10. November 1864, EZA 7, Nr. 19141, 87.

${ }^{16}$ Die Gemeinden und Gutsbezirke der Provinz Preussen und ihre Bevölkerung. Nach den Urmaterialien der allgemeinen Volkszählung vom 1. Dezember 1871 (Berlin: Verlag des Königlichen Statistischen Bureaus, 1874), 330.

17 See, e.g., Archiwum Państwowe Olsztyn (APO), Grundakten Pasken, 42/0/295/2776, 2777, 2778, $2780,2783$.

${ }^{18}$ Förderung des Deutschtums im Kreis Johannisburg 1902-1911, GStAPK, II. HA, Regierung Gumbinnen, Rep. 2, Nr. 3507, Bd. 2, Bl. 8, 15-16, 19, 101.

19 Blanke, Polish-speaking Germans, 55-100.

${ }^{20}$ Kriegsberichte aus dem Regierungsbezirk Allenstein, 2. November 1914, GStAPK, XX. HA, Regierung Gumbinnen, Rep. 2 II, Nr. 3560, Bl. 80; Statistik zu Kriegsschäden 1918-1927; GStAPK, XX. HA, Regierung Gumbinnen, Rep. 2 II, Nr. 3579, Bl. 103, 153; Kossert, Masuren, 233, 239.

${ }^{21}$ Baurat Lange an Ministerium der öffentlichen Arbeiten, 13. Februar 1917, GStAPK, XX. HA, Regierung Gumbinnen, Rep. 2 II, Nr. 3706, Bd. 1, Bl. $2-3$. 
When the Polish state was re-established after the war, the Masurians had to make a decision: would they stay with the German Reich or join the new Poland? A referendum on nationality took place on July 11, 1920 and produced a clear result in favor of the German Reich. However, it introduced the poison of growing nationalist strife, ${ }^{22}$ which heated up in the course of the inter-war period and sometimes even led to firefights along the border. ${ }^{23}$

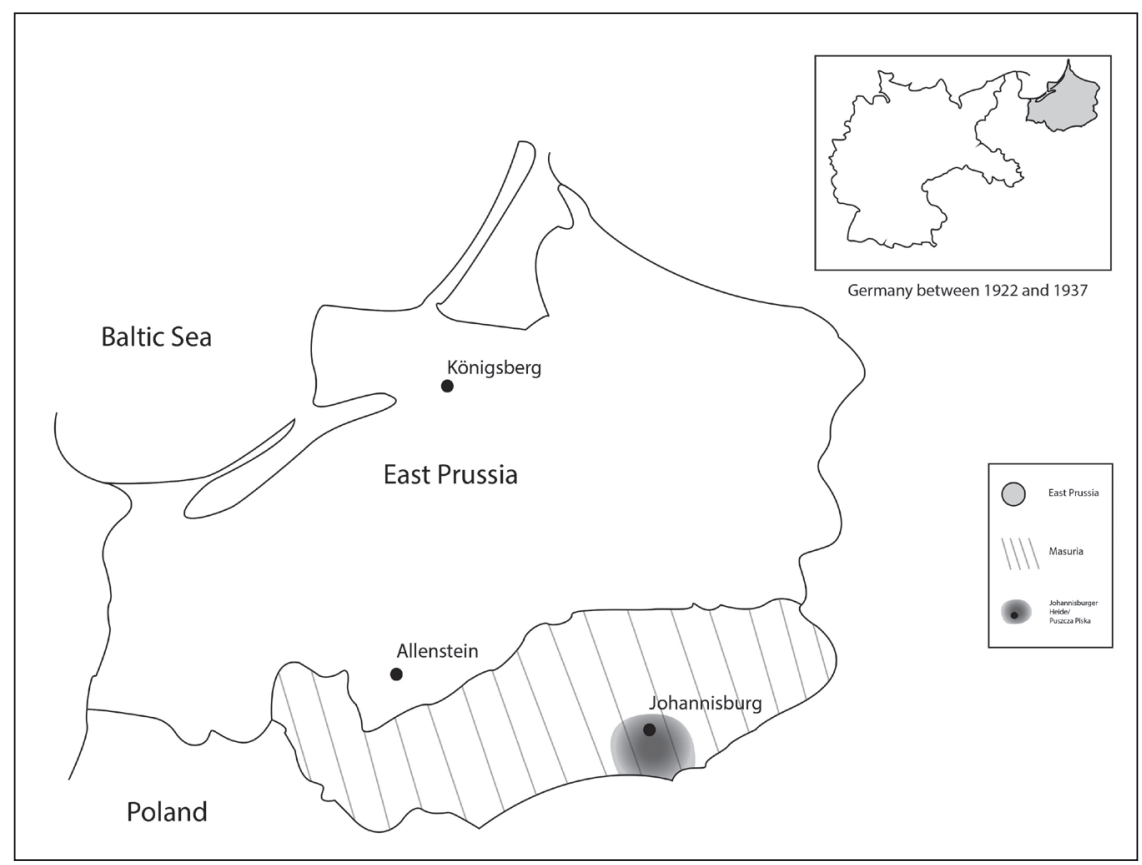

Figure 2: Masuria after the border delimitation following the 1920 plebiscite Design: Leo Grabowski

22 Florian Paprotny, "Die Plebiszite von 1920 - ein Votum für Ostpreußen. Eine Online-Ausstellung," http://martin-opitz-bibliothek.de/de/news-events/aktuelle/die-plebiszite-von-1920 -ein-votum-fur-ostpreussen.

${ }^{23}$ Beispiele in Grenzschutz Osten, 1920, GStAPK, I. HA, Innenministerium, Rep. 77, Tit. 1814, Nr. 6.

\section{8}


In the 1920s and 1930s, the Masurians benefited from state subsidies for reconstruction paid by Germany from funds aimed at supporting Germanness. A certain degree of agricultural restructuring took place, which had started even before the war. If in the nineteenth century the focus had been on timber production, now the production of milk and meat was at the fore. Growing fodder such as oats, barley and clover proved to be more productive than rye, buckwheat or potatoes. In the 1930 s, quite a number of farmers were able to invest in agricultural machinery and vehicles. ${ }^{24}$ Their modest degree of wealth was obvious in comparison to their neighbors in the Polish regions beyond the border, which had suffered much more from acts of war during World War I. The economic difference increased smuggling across the border and attracted Polish seasonal laborers to the Masurian fields. However, such "trade contacts" did not bring the two peoples closer together. ${ }^{25}$ The youngest generation of Masurians, who had exclusively learned German at school and in Sunday school, increasingly considered themselves "East Prussians." Masurian or Polish was the language only of the elderly and farmhands. ${ }^{26}$

The consequences of the Prussian policy of Germanization, together with propaganda about the "Polish threat" and insecurity caused by the overall economic situation, made the Masurians receptive to the political promises of the NSDAP. The Masurians were counted among the party's most faithful followers. In the Reichstag elections of July 31,1932 , more than two thirds of the voters in the Johannisburg district voted for Hitler's party. ${ }^{27}$ After the NSDAP took power the following year, Germanization efforts became even more radical. The Slavic roots of the Masurians were reinterpreted and newly found in Prussian tribes that were said to have been of Baltic origin. From 1938 onward, the National Socialists germanized place names. Thus, the Pissek river became the "Galinde," and Niedzwedzen became "Reinersdorf." ${ }^{28}$ Individual Masurians even germanized their Polish-sounding family names, such as one family whose name had frequently appeared in the archives as Pissowotzki since the fifteenth century but now had renamed themselves "Prange." 29

At the end of the Second World War, when the Red Army advancing towards Berlin reached pre-war German territory for the first time, the Masurians were hit by the full power of Soviet hate and vengeance. The Masurian villages in the Johannisburger Heide, which were located immediately next to the old border, went up in flames. The people

${ }^{24}$ Guttzeit, ed., Der Kreis Johannisburg, 125-127.

25 Robert Traba, "Anpassen, abstoßen oder leben lassen? Die ostpreußische Südgrenze als identitätsstiftender Faktor für die Masuren und ihre polnischen Nachbarn im 19. und 20. Jahrhundert," in Grenzen und Grenzräume in der deutschen und polnischen Geschichte. Scheidelinie oder Begegnungsraum? ed. Georg Stöber and Robert Maier (Hannover: Hahnsche Buchhandlung, 2000), 183-203.

26 Blanke, Polish-speaking Germans, 237-238.

${ }^{27}$ Kossert, Masuren, 298-299; Blanke, Polish-speaking Germans, 255.

${ }^{28}$ After an inhabitant who had immigrated from Salzburg in the eighteenth century.

${ }^{29}$ Bundesarchiv Bayreuth, BArch LAA ZLA 1/5336951. In the files of the BArch LAA, the former inhabitants of the village of Pasken frequently used the name "Galinde," which was introduced by the National Socialists, for Pissek. 
took flight to the West. Not even those who later returned to their destroyed villages were able to keep their homes. They met looters from the surrounding region who took all their property and destroyed the last remnants of their houses down to the ground. ${ }^{30}$ Southern East Prussia came under Polish administration, and the new rulers demanded a clear confession of Polishness from the Masurian people, something many were not willing to do. ${ }^{31}$ The difficult economic conditions as well as the new social-political circumstances of Communist rule did the rest; the majority of Masurians left the Land of a Thousand Lakes as soon as possible and the destroyed villages of the Johannisburger Heide were not reconstructed. After a history of 500 years of settlement, they were lost. Their remains were overgrown by moss and brush and they were forgotten.

\section{The "Lost Villages of Masuria" Project}

Whoever strolls through the Johannisburger Heide/Puszcza Piska today will at best see the old network of roads and some bushes that suddenly appear in a wood where a settlement had once been. However, there is still one piece of evidence that has at least partly survived the destruction to tell about the life of the Masurians. In the thick of the dense vegetation, the cemeteries of the lost villages can be found. These Protestant cemeteries were a crucial element of the cultural landscape of the Masurian lake lands. Each village had its own cemetery. Not infrequently, even individual families had their own burial places, with particular features of design. ${ }^{32}$ In addition to the destruction caused by World War II and politically motivated attempts to extinguish all traces of what was believed to be German, thoughtless vandalism caused massive damage to the old cemeteries. Nevertheless, the surviving remnants still tell us about life in the past in this European border region. Preserved individual gravestones keep the names of former inhabitants alive, tell their dates of birth and death and, by their designs and the ways in which they were made, inform about the standards of living and the preferences of the Masurians, as well as about the blows of fate that they suffered.

30 Traba, “Anpassen," 202-203.

31 On this, see Renata Gieszcyńska, "Der Regierungsbevollmächtigte für den Bezirk Masuren Jakub Prawin - und sein Handeln gegenüber der deutschen Bevölkerung," in Die Haltung der kommunistischen Behörden gegenüber der deutschen Bevölkerung in Polen in den Jahren 1945 bis 1989, ed. Adam Dziurok, Piotr Madajczyk, and Sebastian Rosenbaum (Gliwice/Gleiwitz, Opole/ Oppeln: Dom Współpracy Polsko-Niemieckiej/Haus der Deutsch-Polnischen Zusammenarbeit, Instytut Studiów Politycznych Polski Akademii Nauk/Institut für Politische Studien der Polnischen Akademie der Wissenschaften, 2015).

32 Anna Długozima, "Fenomen cmentarzy warmińskich i mazurskich w aspekcie ich położenia w krajobrazie," in Nekropolie Warmii i Mazur, ed. Wiktor Knercer and Beata Wacławik (Olsztyn: Zakład Poligraficzny "Spręcograf," 2016), 15-42. 


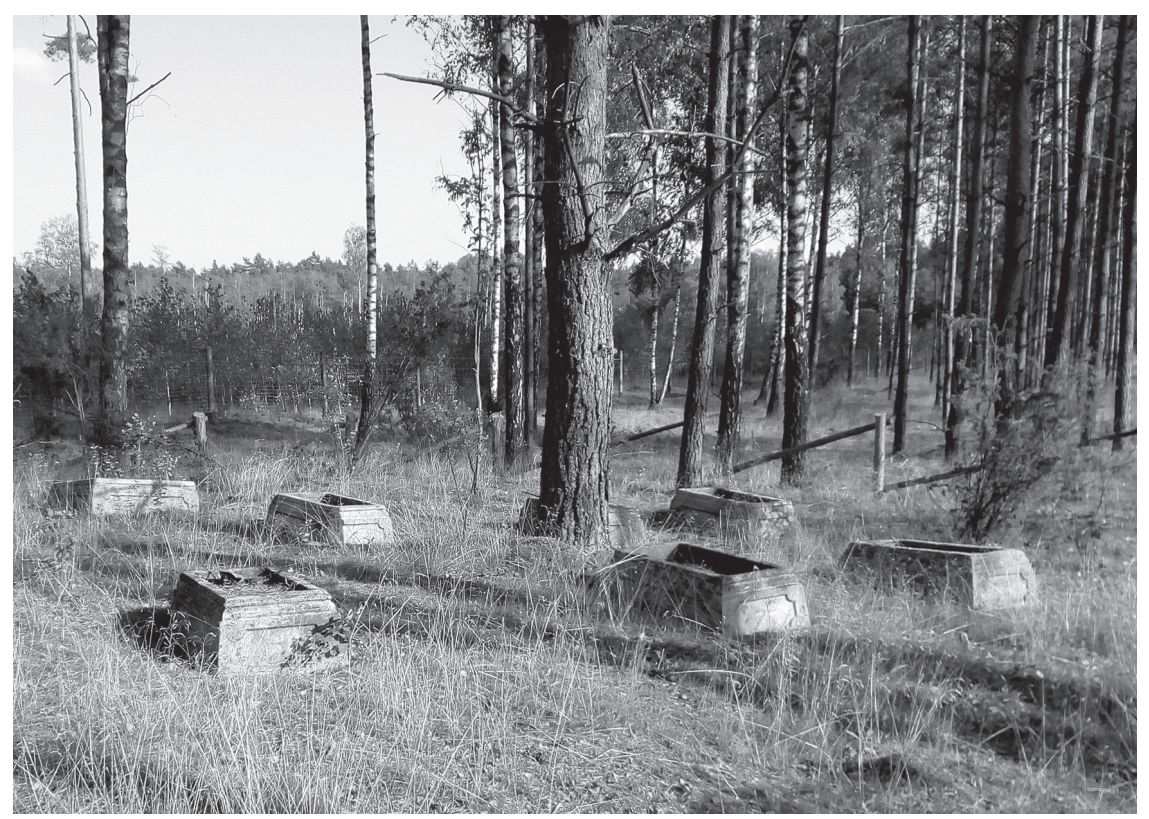

Figure 3: Cemetery of Groß Pasken/Paski Wielkie, 2017

Author: Sabine Grabowski

The history of the lost villages is all but unknown to Masuria's current inhabitants. As a consequence of World War II, the expulsion of the Germans and the forced resettlement of Poles and Ukrainians coming from formerly eastern Polish territory that is today part of Russia, there was an almost complete turnover of the population in the former German province of East Prussia. These "new Masurians" had no relationship with the landscape, the area's cultural heritage or the history of the region. ${ }^{33}$ There were bitter feelings towards everything German as a consequence of the brutal German war of extermination, and the political attitude of the region's new Polish rulers aimed to destroy all traces of German settlement. This resulted in the legal liquidation of old cemeteries and the re-use of their gravestones. ${ }^{34}$ Shattered gravestones and plaques used as tables or flooring are no rarity in the region today.

${ }^{33}$ Dominik Krysiak, Warmia i Mazury w latach 1945-1950. Ksztattowanie się stosunków politycznych i narodowościowych (Olsztyn, Białystok: Instytut Pamięci Narodowej, 2013).

34 Wiktor Knercer, "Ślady na ziemi - cmentarze," in Nekropolie Warmii i Mazur, ed. Wiktor Knercer and Beata Wacławik (Olsztyn: Zakład Poligraficzny "Spręcograf," 2016), 11-12. 
The political and social frame for dealing with the cultural heritage of the old Masurians changed along with the democratic changes of the 1990s. Local initiatives were started to preserve the cultural heritage of the region, which included preserving relics and researching historical relationships. Their participants were interested in exploring the roots of their home region and in preventing further decay of its cultural heritage. The various projects differed from each other in their approaches according to local conditions and the historical objects with which they were dealing. In the Johannisburger Heide, the "Sadyba Mazury" initiative was founded, which attempts to research and document the history of the lost villages and their cemeteries, and at the same time provide an experience of them for younger generations. ${ }^{35}$ The chairman of the association, Krzysztof A. Worobiec, was inspired by reading the two-volume novel Die Jeromin-Kinder by the Masurian author Ernst Wiechert, which was published in 1945-1947. ${ }^{36}$ In his work, Wiechert tells the story of the Jeromin family from Sowirog/Sowiróg on Lake Niedersee/ Jezioro Nidzkie. His detailed, precise depiction of the modest everyday life of a charcoal burner and his children among the forests and lakes fascinated Worobiec, a local historian. It made him look for traces of the actual village that served as the model for the one in the literary story. However, Sowiróg today is nothing more than a name on a map. The village itself has disappeared and only its cemetery can still be found. From Worobiec's search for Sowirog there developed a project to locate the lost villages of Johannisburger Heide, write down their history, ${ }^{37}$ and make their cemeteries visible again. Furthermore, through international workshops for young adults and classes in the local schools, the public was informed about the historical context, supporting a new regional awareness. Since 2009, Sadyba Mazury has already conducted five international work camps, in the course of which ten overgrown cemeteries have been cleared and provided with fencing and information signs, in cooperation with the local forestry institution. This small Masurian association is supported by the foundation Borussia/Fundacja Borussia from Olsztyn which runs a variety of projects connected to the cultural heritage of the region. ${ }^{38}$ Since 2017 the foundation Gerhart-Hauptmann-Haus/Deutsch-osteuropäisches Forum in Düsseldorf has joined as another project partner. ${ }^{39}$

In the context of this German-Polish cooperation, students of history at Heinrich Heine University, Düsseldorf, are brought into contact with students of landscape architecture at the University of Warmia and Mazury/Uniwersytet Warminsko-Mazurski in Olsztyn. Together they discuss the history of the lost villages from the point of view of their respective disciplines. They take trips to Masuria, as part of which the German students visit the archives where material about the history of Masuria is to be found. First

\footnotetext{
35 Homepage of the association, Stowarzyszenie na Rzecz Ochrony Krajobrazu Kulturowego Mazur "Sadyba," https://sadybamazury.wordpress.com.

${ }^{36}$ Ernst Wiechert, Die Jeromin-Kinder, 2 Vol. (München: Zinnen-Verlag, 1945-1947).

${ }^{37}$ Krzysztof A. Worobiec, Zagubione wioski Puszczy Piskiej. Nieznana historia mazurskiego pograni$c z a$ (Olsztyn: Borussia, 2018).

${ }^{38}$ Fundacja Borussia Olsztyn, http://www.borussia.pl.

${ }^{39}$ Gerhart-Hauptmann-Haus - Deutsch-osteuropäisches Forum, http://www.g-h-h.de.
} 
among these archives is the Geheimes Staatsarchiv Preußischer Kulturbesitz (GStAPK) in Berlin-Dahlem. There the future historians are given access to the files of the Prussian authorities up to 1945. Among these are files of the Ministries of Interior, Agriculture, and Culture, and correspondence of the Prefecture of Königsberg and the regional authorities of Gumbinnen and Allenstein, which had authority over Masuria. At the same time, files from the early modern age, such as the Generalhufenschoss (Prussian tax files from the eighteenth century) must be examined, as well as the files of the Teutonic Order, of course. Most of the local foundations in Masuria resulted from the activities of the Teutonic Order in the fourteenth and fifteenth centuries. The medieval grants of privileges, names, and information about acreages are found in the archives of the Order in Berlin-Dahlem. For future historians, a visit to the GStAPK is often their first contact with an archive. The students learn how to use an archive and are confronted with original sources. Such an encounter is not without difficulty, because the manuscripts are not easy to decipher - they are written in the medieval clerical script, in German cursive or in Sütterlin script.

Another station the students visit on their research trip is the Archiwum Państwowe w Olsztynie (the State Archive in Allenstein, APO). Apart from the files of the prefecture and the regional authority, remnants of district files and above all the land registers of the villages are to be found there. Assessing them has proven to be very valuable for analyzing the social structures of the lost villages. Here we find records of real estate sales, marriages, and inheritances through which the social structure of the villages can be understood. The students are challenged by looking through the sometimes voluminous material, while at the same time they must decide what is of significance for reconstructing the history of a certain village.

The German historians are assisted by students of landscape architecture from Olsztyn in these activities. German and Polish students meet for the first time in Olsztyn. They get to know each other and get first impressions of their counterparts' research work and fields of study. Whereas the historians are fascinated by the contracts they find among the files, the future landscape architects are rather more interested in the maps that sometimes accompany the contracts.

After this first meeting, the focus turns to joint fieldwork. From Olsztyn, the group moves on to Pisz/Johannisburg, where they are accommodated during the work camp. The district town of Johannisburg, founded as Jansbork by the Teutonic Order in 1346, was the administrative and economic center of the Johannisburger Heide until $1945 .{ }^{40}$ The town forms the base from which the lost villages of the Heide are explored. The 2017 work camp focused on making the cemeteries in the former villages of Groß Pasken/ Paski Wielkie and Klein Pasken/Paski Małe visible again. In 2018 the camp focused its attention on the villages of Wilken/Wilki and Niedzwedzen/Reinersdorf/Niedźwiedzi. In 2019, the focus will be on the village of Dziadowen/Königstal/Dziadowo. In the course of their work on the cemeteries, the students clear the overgrown graves of moss and

${ }^{40}$ Wydra, Der Kreis Johannisburg. 


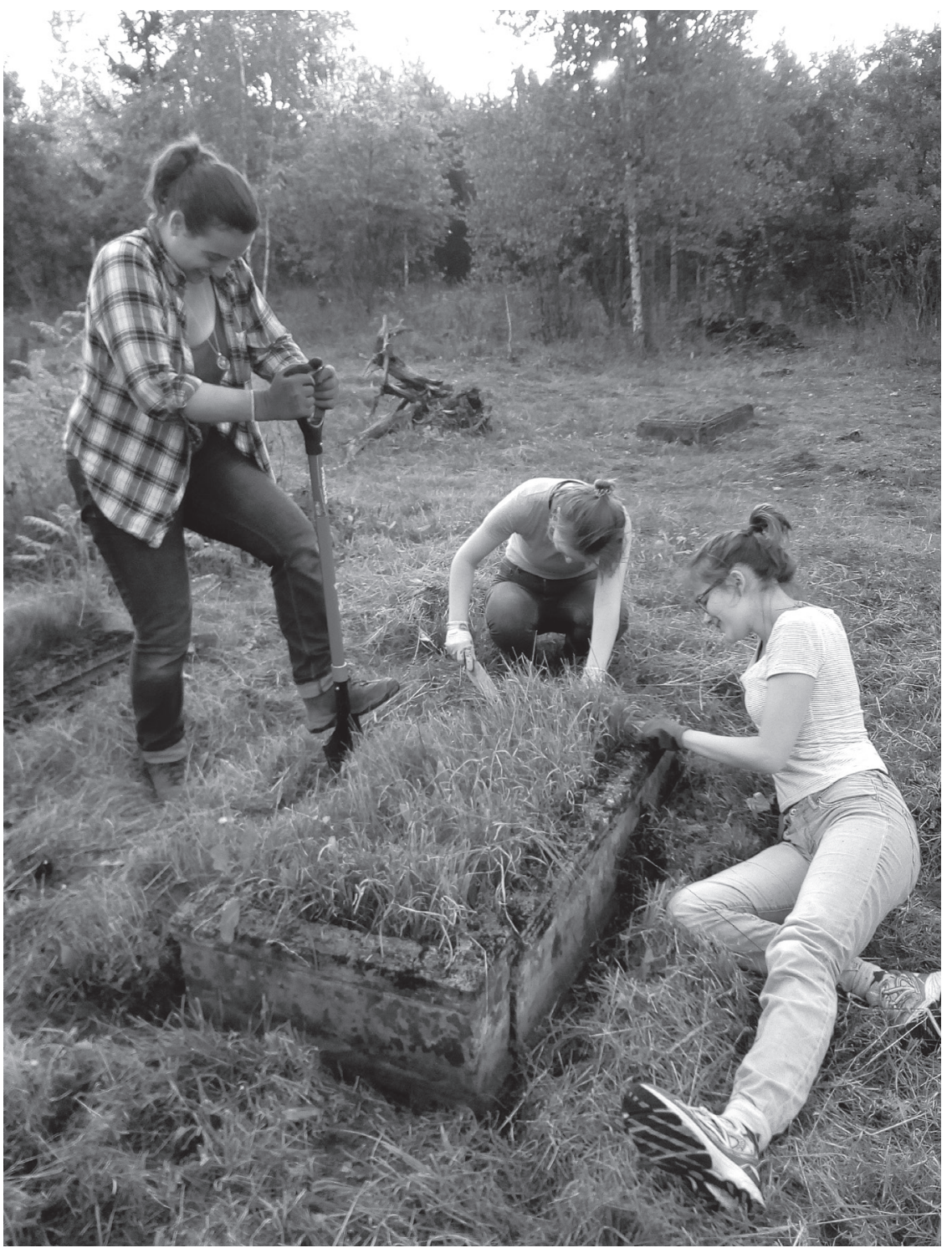

Figure 4: Students working on the cemetery of Wilken/Wilki, 2018

Author: Sabine Grabowski 
scrub, repair the curbs around graves, and decipher inscriptions. Assisted by the Office of the Head Forester at Pisz, trees that have grown up on the graves are felled. The future landscape architects take on the task of measuring, documenting and inventorying the graves that are uncovered. Based on their findings, they produce detailed maps of the cemeteries. Meanwhile, the historians check to see if the names on the gravestones match those on their documents, in order to reconstruct the biographies of individual people. They are not always successful, but sometimes they discover impressive stories that shed light on the fates of the lost villages. The results the German and Polish students jointly produce are summed up in a final presentation and are preserved in a written document.

When they clear the forest, the students are helped by students from the local lyce$\mathrm{um}^{41}$ in the area. First, the local young people take part in introductory lectures about the project, to learn about the historical framework of the founding and destruction of the lost villages. They then participate in practical work at the sites. They have the task of ensuring the cemeteries will be maintained in the future and will not be overgrown again. In that way they take responsibility for the survival of the cultural heritage of their home region.

The balance after two projects of this kind of work is definitely positive. All participants praised the practical experience they gained by taking part in the work camps. The combination of subject-specific, practical work and physical effort to clear the forest was very much welcomed by the students from both disciplines. Both sides were of the opinion that the insights they gained were very fruitful. The knowledge the students obtained about the region of Masuria and its historical connections led to lively debates among the group, and a desire for future cooperation. They are looking forward to a visit by the Polish participants to Düsseldorf and preparing a traveling exhibition.

Cooperation with the students from the local lyceum is just as important. The young people are educated by dealing with their immediate environment and becoming aware of the multi-faceted cultural heritage of their own home region. A certain degree of alienation toward the region is still felt by the grandparents of today's younger generation. Some of their elders were forced to migrate to the region, but young people born in the 2000s are not put off by that. However, they are not very aware of the events that made the fate of their home region a hotly debated issue between German and Poles in the nineteenth and twentieth centuries. Their awareness must first be raised and the context must be explained, so that they can relate the history of the region to their own family histories. The personal commitment of the students to repairing the cemeteries supports their respect for the burial places as well as the people buried there. Their respect for the past will contribute to preventing future vandalism at the cemeteries and strengthen their interest in their common cultural heritage.

In order to communicate the significance of the old cemeteries to the broader public, the Sadyba Mazury initiative has started to place information signs in German and Polish at relevant places in the Johannisburger Heide to inform visitors about the former villages

${ }^{41}$ I Liceum Ogólnokształcące w Piszu im. Bojowników o Polskość Mazur, http://www.zso.pisz.pl. 
and the burial places. These signs are located along an extensive network of cycling paths which are based on old cart tracks through the forest between the lost villages. They improve the tourism infrastructure in what is today a popular holiday region. ${ }^{42}$

Beyond all this, what has resulted from the two work camps of this German-Polish cemetery project when it comes to preserving the history of the disappeared Masurian villages?

The design of the project, with its different participants and contact partners, allows its results to be presented in several different ways. On the one hand, there is the publication of scholarly papers, ${ }^{43}$ on the other hand the results are briefly presented on the local information signs. ${ }^{44}$ Finally, they will be presented in a documentary film about the 2017 work camp. ${ }^{45}$ Presentations in other media formats, such as short films that can be downloaded with the help of a QR-code on the information signboards and a bilingual traveling exhibition, are already in preparation.

Micro-studies of individual villages and their inhabitants allow for development of a basis for comparison of the social and economic structures of various parts of the district. Furthermore, the analysis of the structure of property ownership, drawing on additional material from the Lastenausgleichsarchiv (Equalization of Burdens Archives) where reports on property at the end of the Second World War are to be found, allows for assessment and augmentation of the results gained elsewhere. With the help of individual family histories, it is possible to make detailed statements about how events at the macro-level influenced the deeply interwoven social and economic structure of the Masurian population. Based on the results of the two work camps in 2017 and 2018, it can be stated, for example, that there was a significant difference in the level of economic development between the villages of Klein Pasken and Groß Pasken on the one hand and the villages of Wilken and Niedzwedzen on the other. The latter villages were physically much closer to the district capital of Johannisburg. Not least, this difference can be noticed in their cemeteries. The higher quality of the grave decorations in Wilken and Niedzwedzen reflects the economic prosperity of those settlements.

The individual family histories investigated in the course of the research work contribute to a better understanding of general trends. To begin with, the language in which property and inheritance contracts and their amendments are written demonstrates the language most frequently spoken by individuals - or which they felt safe to use when

42 Tourist map titled Z nurtem Pisy przez Puszczę Piska - śladami przyrody i historii (Pisz: Fundacja Ekonomii Społecznej Wskazówka, 2018).

43 Andreas Göttmann et al., "Pasken - die Geschichte eines verlorenen Dorfes in Masuren. Paski Historia zaginionej wsi na Mazurach," in Znad Pisy. Wydawnictwo poświęcone Ziemi Piskiej 25 (2019), 111-135.

${ }^{44}$ See a photo of a board presenting the cemetery in Sowiróg, https://sadybamazury.wordpress .com/i-edycja-2009/\#jp-carousel-2059.

45 Daniel Raboldt, Im Rücken der Geschichte, 2017, documentary, 0:36:00. For more information on the film, see http://www.nocturnus-film.de/home/projekte/im-ruecken-der-geschichte -dokumentarfilm. 
it came to negotiating contracts - at different times. This allows us to learn the ways in which each respective generation perceived itself. For example, we learn that a particular woman spoke only Masurian all her life; however, her children had the inscription on her gravestone carved in German. She herself would not have been able to read it. ${ }^{46}$

Assessing more cemeteries of the lost villages during future German-Polish work camps will enlarge the database for comparing dates, economic information and family histories. The information the students gather will help us to gain a more differentiated idea of the common cultural heritage of this European border region.

Sabine Grabowski doi: $10.14712 / 23363231.2020 .5$

46 Göttmann et al., Pasken - die Geschichte, 127. 